Darrow, G.M. 1959. Polyploidy in fruit improvement. Scientific Monthly 25:211-219.

Dermen, H. 1944. A general cytohistological study of colchicine polyploidy in cranberry. Amer. J. Bot. 31:451-463.

Dermen, H. 1947a. Inducing polyploidy in peach varieties. J. Hered. 38:77-82.

Dermen, H. 1947b. Polyploid pears. J. Hered. 38:189-192.

Dermen, H. 1952. Polyploidy in the apple found seven years after colchicine treatment. J. Hered. 43:7-8.

Dermen, H. 1954. Colchiploidy in grapes. J. Hered. 45:159-172.

Dermen, H. and G.M. Darrow. 1938. Colchicine-induced tetraploid and 16ploid strawberries. Proc. Amer. Soc. Hort. Sci. 36:300-301.

Dewey, D.R. 1979. Some applications and misapplications of polyploidy, p. 445-470. In: W. Lewis (ed.). Polyploidy. Plenum Press, New York.

Eigsti, O.J. 1938. A cytological study of colchicine effects in the induction of polyploidy in plants. Proc. Natl. Acad. Sci. (USA) 24:56-63.

Eigsti, O.J. 1992. Introduction/H. Kihara, p. 554-556. In: J. Janick (ed.). Classic papers in horticultural science. Prentice Hall, Englewood Cliffs, N.J.

Eigsti, O.J. and P. Dustin, Jr. 1955. Colchicine in agriculture, medicine, biology and chemistry. Iowa State College Press, Ames.

Einset, J. and C. Pratt. 1975. Grapes, p. 130-153. In: J. Janick and J.N. Moore (eds.). Advances in fruit breeding. Purdue Univ. Press, West Lafayette, Ind.

Emsweller, S.L. 1947. The utilization of induced polyploidy in Easter lily breeding. J. Amer. Soc. Hort. Sci. 49:379-384.

Hancock, J.F. 1992. Plant evolution and the origin of crop species. Prentice Hall, Englewood Cliffs, N.J.

Johnston, F.E., Jr. 1939. Chromosome doubling in potatoes induced by colchicine treatment. Amer. Potato J. 16:288-304.

Kihara, H. 1951. Triploid watermelons. Proc. Amer. Soc. Hort. Sci. 58:217230.

Keep, E. 1975. Currants and gooseberries, p. 197-268. In: J. Janick and J.N. Moore (eds.). Advances in fruit breeding. Purdue Univ. Press, West Lafayette, Ind.

Levin, D.A. 1983. Polyploidy and novelty in flowering plants. Amer. Naturalist 122:1-25.

McNaughton, I.H. 1995. Turnip and relatives, p. 45-48. In: J. Smartt and N.W.
Simmonds (eds.). Evolution of crop plants. Longman Scientific and Technical, Essex, England.

Mehlquist, G.A.L., C.O. Blodgett, and L. Bruscia. 1943. Colchicine induced tetraploidy in Delphinium cardinale. J. Hered. 34:187-192.

Myers, W.N. 1939. Colchicine induced polyploidy in perennial rye grass. J. Hered. 30:499-504.

Nebel, B.R. and M.L. Ruddle. 1938. The cytological and genetical significance of colchicine. J. Hered. 29:3-9.

Ourecky, D.K. 1975. Brambles, p. 98-129. In: J. Janick and J.N. Moore (eds.). Advances in fruit breeding. Purdue Univ. Press, W. Lafayette, Ind.

Pal, B.P. and S. Ramanujan. 1939. Induction of polyploidy in chili (Capsicum annuus) by colchicine. Nature 143:245-246.

Rasmussen, J. and A. Levan. 1939. Tetraploid sugar beets from colchicine treatments. Hereditas 25:97-102.

Sears, E.R. 1939. Amphidiploids in the triticale induced by colchicine. J. Hered. 30:38-43.

Smith, H.H. 1939. The induction of polyploidy in Nicotiana species and species hybrids. J. Hered. 30:291-306.

Sparnaaij, L.D. 1979. Polyploidy in flower breeding. HortScience 14:496-499.

Stebbins, G.L. 1956. Artificial polyploidy as a tool in plant breeding, p. 37-52. Genetics and Plant Breeding, Brookhaven Symp. in Biol.No. 9, Brookhaven Natl. Lab., Upton, N.Y.

Thompson, R.C. and W.F. Kosar. 1939. Polyploidy in lettuce induced by colchicine. Proc. Amer. Soc. Hort. Sci. 36:641-644.

U.S. Department of Agriculture. 1953. Man made polyploids can save a million years. Agr. Res. (October). U.S. Dept. Agr., Washington, D.C.

U.S. Department of Agriculture. 1955. Big grapes coming. Agr. Res. (December). U.S. Dept. Agr., Washington, D.C.

U.S. Department of Agriculture. 1956. Big apple with a big future. Agr. Res. (January). U.S. Dept. Agr., Washington, D.C.

Van't Hoff, J. and A.H. Sparrow. 1963. A relationship between DNA content, nuclear volume and minimal cell cycle time. Proc. Natl. Acad. Sci. (USA) 49:897-902.

Vallareal, R.L., G. Varughese, and O.S. Abdulla. 1990. Advances in spring tricale breeding. Plant Breed. Rev. 8:43-90.

\title{
Commercial Micropropagation
}

\author{
S.L. Kitto \\ Delaware Agricultural Experiment Station, Department of Plant and Soil Sciences, College of Agricultural \\ Sciences, University of Delaware, Newark, DE 19717-1303
}

The origins of tissue culture derive from the pioneering research of Gottlieb Haberlandt (1902) who first attempted to culture isolated plant cells. Clonal propagation via tissue culture, i.e., micropropagation, as a concept was first presented to the scientific community in 1960 (Morel, 1960). The necessary tools that made micropropagation a possibility, such as the development of media and an understanding of growth regulators, have been available only since the late $1950 \mathrm{~s}$, and it was not until the early 1960 s that a generalized culture medium was established. The history of tissue culture can be gleaned from the introductions to classic papers in this area by Joseph Arditti, A.D. Krikorian, Peter Carlson, Roberta Smith, and J.H. Gould (Janick, 1989). The actual establishment of commercial micropropagation as an industry became a reality during the 1970 s and 1980 s. Thus, the micropropagation industry is only 15 to 20 years old (Jones and Sluis, 1991; Zimmerman and Jones, 1991), and retrospectives on commercial micropropagation are few and far between.

Has commercial micropropagation delivered all that it promised? No. Must the entire micropropagation community be defensive because a few early proponents prophesied that micropropagation would be the answer to many (if not all) problems associated with conventional propagation? Probably yes.

Received for publication 4 Mar. 1997. Accepted for publication 4 Apr. 1997. Published as paper no. 1588 in the Journal Series of the Delaware Agricultural Experiment Station. The cost of publishing this paper was defrayed in part by the payment of page charges. Under postal regulations, this paper therefore must be hereby marked advertisement solely to indicate this fact.
Like many areas of research, endeavors such as micropropagation that initially appear to be simple transform themselves into a Pandora's box full of questions. Even today much is not fully understood about micropropagation, and although general guidelines for micropropagation have been established, each plant species is unique. Despite these problems, there are a large number of species being micropropagated on a commercial scale throughout the world (see Henley, 1992).

The advantages associated with micropropagation include yearround production of clonally identical, pest-free plants. Micropropagation offers the possibility of rapid clonal production of superior plants or lines for commercial sale where demand is high and supply is low or for establishment of plantings for special uses in a compressed time frame (Murashige and Huang, 1987).

My objective is to present data supporting the viewpoint that commercial micropropagation is alive and well and has been and will continue to be fashionably correct, much like the classical white Oxford button-down shirt. I will review commercial micropropagation and the worldwide distribution of laboratories, with specific emphasis on the industry in the United States. I also will cover barriers and stumbling blocks, both scientific and business-related, facing commercial micropropagation.

\section{DISTRIBUTION AND PRODUCTION}

Surveys conducted in the late 1980 s reported 248 commercial micropropagation laboratories in Western Europe (with $15 \%$ produc- 
ing more than a million plants per year) and 250 laboratories in the United States. More than 500 million plants were produced worldwide of which $50 \%$ were produced in Eastern and Western Europe, $27 \%$ in Asia, and $22 \%$ in the United States (Jones, 1987; Pierik, 1991). Indepth reviews of the commercial industries in Eastern Europe; Asia; Oceania; Africa; and South, Central, and North America are available in Debergh and Zimmerman (1991).

In The Netherlands from 1980 to 1988, the number of laboratories increased from 28 to 76 , which produced about one-third ( 80 million) of the micropropagated plants in Western Europe (Pierik, 1991).

In the United States, more than half of the 250 laboratories were located in California (76), Florida (36), Texas (14), and New York (16), and five of the top seven nurseries had tissue-culture laboratories (Jones, 1987). A more recent survey of micropropagators in the United States ( 125 respondents representing 32 states) indicated that $53 \%$ (66 laboratories) were privately owned, with 38 of those being commercial laboratories, as opposed to research or hobbyist laboratories, and nearly half $(45 \%)$ operated with $<1000 \mathrm{ft}^{2}$ (Bridgen, 1992).

Henley (1992) found that just tabulating the number of laboratories in Florida on an annual basis gave an inadequate representation of the industry. Although the actual number of commercial laboratories varied little over a 9-year period (11 in 1983 vs. 14 in 1992), closer examination revealed that the commercial micropropagation industry in Florida was quite volatile. Of 14 laboratories present in 1989, four had closed within 2 years (1989-91), one was sold, two changed their names, some of the remaining six expanded, and four new laboratories were started.

The majority $(74 \%)$ of the plants being commercially micropropagated worldwide are ornamentals (cut flowers, foliage plants, orchids, and ferns) (Pierik, 1991). Compared with the United States, the rest of the world micropropagates larger numbers of fruit crops, vegetable crops, and tropical plantation crops (Henley, 1992). This apparent lack of diversity has been attributed to the close association and influence of the floriculture industry (Jones and Sluis, 1991). The United States clearly needs to expand its diversity.

Within the horticultural industry in the United States, micropropagation accounted for $\$ 18$ to $\$ 20$ million in 1985 . In 1992 , micropropagated starter plants were valued at $\$ 34$ million, only $4 \%$ of the total starter plant industry (Henley, 1992).

\section{Scientific barriers}

Of about 1000 plant types reportedly micropropagated (Murashige and Huang, 1987), not all can be micropropagated on a commercial scale. Micropropagation remains a popular research subject; since micropropagation was first used as an index word in Agricola in 1976 more than 2200 entries have been listed in this category. Continued research is definitely needed to focus on increasing the speed with which some plants can be produced while producing a superior quality product that is competitively priced. There is often inadequate research in the development of protocols for proliferation, rooting, acclimation, and reestablishment. Transplanting problems still exist. The ability to successfully take a plant, especially woody plants, through the four stages of micropropagation and consistently produce healthy, saleable plants still remains a challenge and requires coordinated planning.

Testing for the presence of pathogens unfortunately is not a routine procedure and many laboratories produce pathogen-free plants by coincidence rather than by design (Murashige and Huang, 1987).

There is a great need for increased automation, as the majority of the costs associated with micropropagation are related to hand labor (Murashige and Huang, 1987; Zimmerman and Jones, 1991). Research funding, both private and public, needs to be increased if scientific barriers are to be resolved in a timely manner.

The success of micropropagation is clearly dependent on maintaining the genetic integrity of a propagule to guarantee clonal identity. Practices that do not guarantee the maintenance of clonal identity, e.g., regenerative processes, need to be avoided until such time that the causes of somaclonal variation are understood and controllable (Reuveni et al., 1993).

\section{Business-related barriers}

Volatility in the micropropagation industry can be linked directly with "business-world" phenomena. After 5 years, $80 \%$ of new businesses no longer exist and after 10 years, fewer than $10 \%$ exist. The overall economic environment also must be considered. The extensive growth experienced by the micropropagation industry during the 1980 s has probably contributed to the slowdown associated with the 1990s (Zimmerman and Jones, 1991).

In the early years, micropropagation firms sold to finishing nurseries and expected nursery operators to educate themselves as to the handling and marketing of quality micropropagated plants (Jones and Sluis, 1991; Standardt-de Metsenaere, 1991). This is changing. Micropropagation firms are usually directly aligned with a nursery to better ensure the high quality of the finished plants.

Successful commercial micropropagation requires a strategy to produce a large number of quality plants using very labor-intensive protocols based on a highly trained labor force. But the ability to produce a large number of high-quality plants does not guarantee success (Jones and Sluis, 1991). Commercial micropropagation companies that have survived and grown have learned that they must determine who will buy their product, how to deliver large numbers of product during a very narrow time frame, how to use their labor effectively year-round, how to produce a competitively priced plant, how to diversify their product line to avoid saturating the market, and how to attract new buyers and get present buyers to "substitute" micropropagated liners for conventional liners (Jones, 1987; Pierik, 1991). Micropropagation must compete with conventional propagation, which often produces a product at a lower cost (Standaert-de Metsenaere, 1991). Finally, micropropagation also is sensitive to prospects/constraints of general agriculture and horticulture (Standaertde Metsenaere, 1991).

Micropropagation is extremely labor-intensive with nearly half $(46 \%)$ of the costs attributable to labor. Research and development accounts for only $1 \%$ ! Cost reductions have been difficult because the cost for labor is directly associated with the transfer and maintenance of cultures (Henley, 1992). One solution is to move to lower-cost labor sites, but there are problems with this strategy (Henley, 1992), including perishability of product, costs associated with long distance communication, and unreliable electrical power sources. Part of the answer clearly lies in automation.

\section{CONCLUSIONS}

Has commercial micropropagation delivered all that it promised? Probably not, but this is due to some of the extraordinarily expansive claims by its early proponents-claims that could not be fulfilled. It has undergone some gigantic failures as a result of the mass production of off-type plants (Reuveni et al., 1993), but this does not reflect a failure of the system but rather a gross misstep due to a combination of incompetence and greed. However, the industry has demonstrated its staying power by continuing to grow, although at a moderate rate, through some very rough economic times. Furthermore, the production of many crops, especially ornamentals, is based on the use of tissue culture and micropropagation at some stage of their development. The ability of micropropagation to deliver disease-free plant material has transformed the foliage plant industry.

Commercial micropropagation is a young industry with an excellent future. It is definitely not a fad. This industry will continue to expand, but expansion will not be explosive without new technology to provide automation and improved protocols for acclimatization. The results of this research should be forthcoming soon and, as a result, I predict micropropagation as an industry will continue to be fashionable for quite some time.

\section{Literature Cited}

Bridgen, M.P. 1992. A survey of plant tissue culture laboratories in North America. Combined Proc. Intl. Plant Propagator's Soc. 42:427-430.

Debergh, P.C. and R.H. Zimmerman (eds.). 1991. Micropropagation. Kluwer Academic Publ., Dordrecht, Netherlands.

Haberlandt, G. 1902. Kulturversuche mit isolierten Pflanzenzellen. Sitzungsber. 
Akad. Wiss. Wien, Math.-Naturwiss. Kl. III:69-92.

Henley, R.W. 1992. Two years of change in Florida's tissue culture industry. Foliage News, IFAS, Univ. of Florida. 16(3)1-6.

Janick, J. (ed.). 1989. Classic papers in horticultural science. Prentice Hall, Englewood Cliffs, N.J.

Jones, J.B. 1987. Commercial plant tissue culture in the United States. Acta Hort. 212:639-643.

Jones, J.B. and C.J. Sluis. 1991. Marketing of micropropagated plants, p. 141154. In: P.C. Debergh and R.H. Zimmerman (eds.). Micropropagation. Kluwer Academic Publ., Dordrecht, Netherlands.

Morel, G.M. 1960. Producing virus-free cymbidiums. Amer. Orchid Soc. Bul. 29:495-497.

Murashige, T. and L.-C. Huang. 1987. Cloning plants by tissue culture: Early years, current status and future prospects. Acta Hort. 212:639-643.

Pierik, R.L.M. 1991. Commercial aspects of micropropagation, p. 141-153. In: J. Prokash and R.L.M. Pierik (eds.). Horticulture-New technologies and application. Kluwer Academic Publ., Netherlands.

Reuveni, O., S. Golubowicz, and Y. Israeli. 1993. Factors influencing the occurrence of somaclonal variations in micropropagated bananas. Acta Hort. 336:357-364.

Standaert-de Metsenaere, R.E.A. 1991. Economic considerations, p. 123-140. In: P.C. Debergh and R.H. Zimmerman (eds.). Micropropagation. Kluwer Academic Publ., Dordrecht, Netherlands.

Zimmerman, R.H. and J.B. Jones. 1991. Commercial micropropagation in North America, p. 173-179. In: P.C. Debergh and R.H. Zimmerman (eds.). Micropropagation. Kluwer Academic Publ., Dordrecht, Netherlands.

\title{
Hormones and Horticulture
}

\author{
Norman E. Looney \\ Pacific Agri-Food Research Centre, Agricülture and Agri-Food Canada, Summerland, B.C. V0H 1Z0, Canada
}

In their book Hormones and Horticulture, Avery and Johnson (1947) confidently stated that

\begin{abstract}
"A chemical revolution is sweeping through the agricultural world. It is unrivalled by any of the previous great advances in agriculture and, perhaps, by most advances in the biological field. For the first time man can change the pattern of growth and development of plants, can retard growth here and speed it there. The growth-controlling hormones...now in use are but crude beginnings."
\end{abstract}

Indeed, by the mid-1940s it was clear to most research horticulturists in North America that if they were to continue to be considered relevant within their chosen field of science they had better climb on board the hormones and horticulture wagon. It reminds me of the present belief (fear plus trust!) that molecular genetics is "where it's at," and even "where it will be" for decades to come.

Still, spectacular progress was made over a relatively few decades in understanding the important capabilities of endogenous "hormones", and demonstrating that plant growth and development could be profoundly influenced by the "plant growth regulators" (PGRs) developed by a confident and forward-looking agricultural chemicals industry. (Since many of these chemicals do not influence growth I prefer "plant bioregulators" and will use PBRs from here on.)

My task is to chart the ascent of the hormones and horticulture era and to reflect on its "staying power." My approach will be to deal with four successive 20- to 40-year "phases" starting in the 19th century. I will present bibliometric data from several sources to support the hypothesis that research on endogenous hormones in horticultural plants and PBR usage in horticultural technology (hormones and horticulture, for short) continues to receive major attention.

Even in the 1990s, when the tools of molecular biology are being applied to answering fundamental questions about hormone action, there is optimism that a new understanding of the relationship between hormones and gene expression will lead to the development of new plant materials and new chemical tools for use in horticulture.

\section{PHASE I. EARLY INVESTIGATIONS 1880-1920}

The discoveries and observations that founded this field of research occurred during the last quarter of the 19th century. Good work in a

Received for publication 4 Mar. 1997. Accepted for publication 4 Apr. 1997. I wish to thank Ms. Peggy Watson, Summerland Research Centre librarian, for her generous assistance with the bibliometric analysis. The cost of publishing this paper was defrayed in part by the payment of page charges. Under postal regulations, this paper therefore must be hereby marked advertisement solely to indicate this fact. relatively few laboratories gave credibility to the concept that endogenous chemical "regulators" might control important aspects of plant growth and development.

Darwin and Darwin (1880) reported their classic experiments on phototropism and geotropism that predicted the existence of a chemical transmitter or messenger. The idea of correlative growth of plant organs was introduced at about the same time by Julius Sachs (e.g., 1880). Sachs' contributions were of immense importance in that he was the first to apply the laws of causality to organ development. $\mathrm{He}$ assumed the existence of root-forming, flower-forming, and other substances that moved in different directions in the plant. However, Boysen-Jensen $(1911,1913)$ appears to have been the first to actually demonstrate, by grafting, that the phototropic stimulus was "chemical" in nature.

The term "hormone" was introduced into animal physiology to denote a substance produced in one part of the organism and transferred to another part to influence a specific physiological process. These specifications, of course, do not always apply in plant systems. Nonetheless, the term hormone was used in plant biology as early as 1910 (Fitting, 1910) and given legitimacy in later reviews such as that by J.S. Huxley (1935). Went and Thimann (1937) confirmed that the "hormone concept" was applicable to plants. The term "phytohormone" was preferred by these latter authors.

\section{PHASE II. THE DISCOVERY AND PROMISE OF AUXIN 1920-1945}

The "modern age" of phytohormones began in the 1920 s when F.W. Went (1928) isolated an active substance from oat coleoptile tips that later proved to be indoleacetic acid (IAA) or auxin. Researchers worldwide joined the chase and by 1937 Went and Thimann noted that the bibliography to their book Phytohormones, published in 1937, included 77 papers published in 1936!

"The field of plant hormones is perhaps now at the stage of its most rapid development. The number of facts is becoming so large, and their distribution through the literature so scattered that there is danger of losing sight of the general trend" (Went and Thimann, 1937).

Furthermore, as suggested by another notable quote, they felt that most of what needed to be known about this subject had already been discovered!

"This survey of the rapidly developing field of phytohormones shows that many problems have been solved and few really important points are still subjects of disagreement." 